\title{
Analisis Efektivitas Sistem Pengendalian Internal Melalui Sanksi Adat dalam Upaya Mengatasi Kredit Bermasalah pada Bumdes Merta Nadi di Desa Bayung Cerik
}

\author{
I Wayan Sopyan Pratama ${ }^{*}$, Nyoman Ayu Wulan Trisna Dewi ${ }^{2}$ iD \\ 12 Jurusan Ekonomi dan Akuntansi, Universitas Pendidikan Ganesha, Singaraja-Bali \\ *iwayansopyanpratama22@undiksha.ac.id ${ }^{\text {* }}$
}

\section{Abstrak}

Penelitian ini bertujuan untuk mengetahui (1) penyebab terjadinya kredit bermasalah pada BUMDes Merta Nadi di Desa Bayung Cerik, (2) strategi dan upaya dalam mengatasi kredit bermasalah pada BUMDes Merta Nadi di Desa Bayung Cerik, (3) efektivitas penerapan sanksi adat dalam mengatasi terjadinya kredit bermasalah pada BUMDes Merta Nadi di Desa Bayung Cerik. Penelitian ini menggunakan metode penelitian dengan pendekatan kualitatif dan jenis penelitian studi kasus. Data dikumpulkan dengan cara observasi, wawancara, dan studi dokumentasi. Teknik analisis data pada penelitian ini meliputi pengumpulan data, reduksi data, penyajian data, kesimpulan dan verifikasi. Hasil penelitian ini menunjukkan bahwa (1) penyebab terjadinya kredit bermasalah pada BUMDes Merta Nadi yaitu disebabkan oleh debitur atau faktor eksternal, strategi dan upaya yang dilakukan BUMDes Merta Nadi dalam mengatasi kredit bermasalah yaitu dengan strategi pemberian kredit berdasarkan prinsip 5C dan upayanya dengan penerapan sanksi adat serta sanksi administrasi, (3) penerapan sanksi adat pada BUMDes Merta Nadi terbilang cukup efektif, karena mampu menumbuhkan rasa malu debitur dan kesadaran untuk melunasi tunggakannya, serta berusaha untuk membayar tunggakan kreditnya.

Kata Kunci : Efektivitas, Sistem Pengendalian Internal, Sanksi Adat, Kredit Bermasalah

\section{Abstract}

This study aims to determine (1) the causes of non-performing loans in BUMDes Merta Nadi in Bayung Cerik Village, (2) strategies and efforts in overcoming non-performing loans at BUMDes Merta Nadi in Bayung Cerik Village, (3) the effectiveness of applying customary sanctions in overcoming the occurrence of nonperforming loans on BUMDes Merta Nadi in Bayung Cerik Village. This study uses research methods with a qualitative approach and the type of case study research. Data were collected by means of observation, interviews, and documentation studies. Data analysis techniques in this study include data collection, data reduction, data presentation, conclusions and verification. The results of this study indicate that (1) the causes of non-performing loans in BUMDes Merta Nadi are caused by debtors or external factors, the strategies and efforts made by BUMDes Merta Nadi in overcoming non-performing loans are the strategy of providing credit based on the $5 C$ principle and its efforts by applying customary sanctions as well as administrative sanctions, (3) the application of customary sanctions on BUMDes Merta Nadi is quite effective, because it is able to grow debtor's shame and awareness to pay off arrears, and try to pay off arrears on credit.

Keywords: Effectiveness, Internal Control System, Customary Sanctions, Non-performing Loans

\section{Pendahuluan}

Bali merupakan salah satu provinsi yang ada di Indonesia yang sangat terkenal namanya hingga ke mancanegara. Bali memiliki delapan kabupaten dan satu kota yang setiap 
kabupaten/kota memiliki beragam keunikan tradisi dan kebudayaan yang sangat sakral yang diwariskan secara turun-temurun oleh nenek moyangnya. Bali juga mengenal dua definisi desa, yaitu yang pertama menurut batas yang tersirat dan tersurat dalam hukum nasional, dalam konteks ini disebut desa dinas. Kedua yaitu desa adat atau desa pakraman, mengacu pada masyarakat adat yang terfokus pada ikatan adat dan terkait dengan kehidupan tiga pura besar (kahyangan tiga) serta berlandasankan sanksi adat (Ernawati, 2019).

Sihotang (2019) mengatakan bahwa sanksi adat adalah segala bentuk tindakan atau usaha-usaha yang dilakukan untuk mengembalikan ketidakseimbangan termasuk pula ketidakseimbangan yang bersifat magis akibat adanya gangguan yang merupakan pelanggaran adat. Desa mempunyai karakteristik yang berlaku umum untuk seluruh Indonesia, sedangkan desa adat mempunyai karakteristik yang berbeda dari desa pada umumnya, terutama karena kuatnya pengaruh adat terhadap sistem pemerintahan lokal, pengelolaan sumber daya lokal, dan kehidupan sosial budaya masyarakat desa. Mengingat tentang banyaknya nama dari setiap wilayah tersebut, maka tidak terlepas dari keberadaan bermacam-macam bentuk kegiatan, dan program-program yang ada di desa. Desa memiliki program untuk memajukan perekonomian desa yaitu didirikannya BUMDes.

Peraturan Pemerintah Nomor 11 tahun 2021 tentang BUM Desa atau BUMDes adalah badan hukum yang didirikan oleh desa dan/atau bersama desa-desa guna mengelola usaha, memanfaatkan aset, mengembangkan investasi dan produktivitas, menyediakan jasa pelayanan, dan/atau menyediakan jenis usaha lainnya untuk kesejahteraan masyarakat desa (Pemerintah, 2021). Sinarwati and Marhaeni (2019) menyatakan pendirian Badan Usaha Milik Desa merupakan wujud kepedulian pemerintah dan masyarakat untuk bersama-sama meningkatkan kesejahteraan masyarakat pedesaan. Badan Usaha Milik Desa diharapkan mampu berperan besar dalam pembangunan pedesaan melalui pengelolaan potensi desa secara optimal, memenuhi kebutuhan masyarakat pedesaan tanpa mematikan usaha-usaha yang ada di desa yang telah didirikan sebelumnya. BUMDes juga memberikan sumbangan bagi peningkatan sumber pendapatan asli desa yang memungkinkan desa mampu melaksanakan pembangunan dan peningkatan kesejahteraan rakyat secara optimal.

Desa Bayung Cerik merupakan desa dinas dan juga desa adat dengan nama yang sama, masyarakat Desa Bayung Cerik merupakan warga desa dinas dan juga warga desa adat dengan orang-orang yang sama. Desa Bayung Cerik mendirikan Badan Usaha Milik Desa (BUMDes) pada tanggal 6 Pebruari 2017 dan diberi nama BUMDes Merta Nadi yang terletak di Kecamatan Kintamani Kabupaten Bangli. Tujuan didirikannya BUMDes Merta Nadi tersebut kedepannya diharapkan mampu meningatkan perokonomian masyarakat Desa Bayung Cerik. Unit usaha yang dimiliki oleh BUMDes Merta Nadi yaitu unit usaha simpan pinjam, dan pengelolaan PAM Desa yang dibantu oleh pecalang desa adat untuk menagih pembayaran PAM Desa.

Usaha simpan pinjam yang didirikan oleh BUMDes Merta Nadi diharapkan dapat membantu masyarakat Desa Bayung Cerik. Pemberian kredit ini mengandung resiko besar bagi bank atau perusahaan apabila debitur tidak memenuhi kewajibannya. Kredit macet yang menimbulkan piutang tak tertagih menjadi salah satu resiko yang timbul atas penjualan kredit (Suak, 2018). Bank atau instansi dalam menyalurkan kredit pastinya didasarkan pada prinsip 5C (Character, Capacity, Capital, Collateral, Conditions) dan 7P (Personality, Party, Perpose, Prospect, Payment, Profitability, Protection) guna mengatasi dan mencegah terjadinya kredit bermasalah ataupun macet (Anggriawan, 2017).

BUMDes Merta Nadi selain menerapkan sanksi adminisrtrasi juga menerapkan sanksi adat guna mengatasi dan mencegah terjadinya kredit bermasalah ataupun macet. Mekanisme sanksi administrasi yang diterapkan untuk mengatasi kredit bermasalah yaitu tidak mendapatkan pelayanan administrasi di kantor perbekel, seperti dalam mencari surat-surat 
dan lain sebagainya, sedangkan mekanisme penerapan sanksi adat yaitu masyarakat tidak mendapatkan pelayanan dari sulinggih/pemangku, bendesa, kelian dinas, kelian adat, serta kelian banjar dalam upacara tiga bulanan, mecaru, mepejati, pernikahan, piodalan, mesangih dan upacaralupakara adat lainnya, karena dalam uparacalupakara tersebut harus terdapat pemangku yang memimpin upacaralupakara dan di saksikan oleh bendesa dan kelian-kelian desa tersebut.

Prosedur penagihan yang akan dilaksanakan sebelum diberikan sanksi administrasi dan sanksi adat, antara lain: (1) Dilakukan penagihan oleh bagian penagihan dan Ketua BUMDes, (2) Pemberian Surat Peringatan (SP) 1-3, (3) Melaporkan masyarakat yang bersangkutan kepada Bendesa adat/Kelian adat, (4) Dilakukan pendekatan secara ke keluargaan oleh Bendesa adat/Kelian adat dan dicari pemecahan masalah sesuai permasalahan yang dialami oleh masyarakat, (5) Jika masyarakat yang bersangkutan tetap tidak mau membayar, maka akan dilaporkan ke Perbekel dan akan dikenakan sanksi administrasi dan sanksi adat tersebut.

Perbandingan kredit bermasalah pada tahun 2019 dan tahun 2020 BUMDes Kecamatan Kintamani disajikan pada tabel 1. Kecamatan Kintamani memiliki 48 desa, namun dari 48 desa hanya 46 desa yang sudah mendirikan BUMDes, dilihat dari tahun berdirinya paling awal dan jumlah nominal kredit yang disalurkan paling banyak hanya terdapat 4 BUMDes dari 46 BUMDes, yaitu BUMDes Merta Nadi, BUMDes Tri Kerta Praja, BUMDes Amertha Yoni, dan BUMDes Bumi Kertih Karanganyar. Penulis akan menyajikan tabel perbandingan kredit bermasalah pada tahun 2019 dan tahun 2020, sebagai berikut:

Tabel 1. Perbandingan Kredit Bermasalah pada Tahun 2019 dan 2020

\begin{tabular}{|c|c|c|c|c|c|c|}
\hline \multirow[b]{2}{*}{$\begin{array}{c}\text { Nama } \\
\text { BUMDes }\end{array}$} & \multirow[b]{2}{*}{ No } & \multirow[b]{2}{*}{ Uraian } & \multicolumn{2}{|r|}{ Tahun 2019} & \multicolumn{2}{|r|}{ Tahun 2020} \\
\hline & & & $\begin{array}{l}\text { Jumlah } \\
\text { Orang }\end{array}$ & Jumlah Rupiah & $\begin{array}{l}\text { Jumlah } \\
\text { Orang }\end{array}$ & Jumlah Rupiah \\
\hline \multirow{5}{*}{$\begin{array}{l}\text { Merta } \\
\text { Desa } \\
\text { Cerik }\end{array}$} & 1 & Lancar & 115 & Rp. 1.245.265.000 & 121 & Rp. 1.429.650.000 \\
\hline & 2 & K. Lancar & 64 & Rp. 270.360 .000 & 58 & Rp. 672.050 .000 \\
\hline & 3 & Diragukan & 0 & Rp. 0 & 0 & Rp. 0 \\
\hline & 4 & Macet & 1 & Rp. 11.380 .000 & 2 & Rp. 5.200.000 \\
\hline & & Jumlah & 180 & Rp. 1.527.005.000 & 181 & Rp. 2.106.900.000 \\
\hline \multirow{5}{*}{$\begin{array}{l}\text { Tri Kerta Praja } \\
\text { Desa Belancan }\end{array}$} & 1 & Lancar & 123 & Rp. 2.704.882.000 & 131 & Rp. 3.449.755.000 \\
\hline & 2 & K. Lancar & 1 & Rp. 15.000 .000 & 5 & Rp. 50.930 .000 \\
\hline & 3 & Diragukan & 0 & Rp. 0 & 0 & Rp. 0 \\
\hline & 4 & Macet & 1 & Rp. 36.000 .000 & 3 & Rp. 6.903 .000 \\
\hline & & Jumlah & 125 & Rp. 2.755.882.000 & 139 & Rp. 3.507.588.000 \\
\hline \multirow{5}{*}{$\begin{array}{l}\text { Amertha Yoni } \\
\text { Desa Katung }\end{array}$} & 1 & Lancar & 85 & Rp. 1.187.160.000 & 124 & Rp. 1.979.892.000 \\
\hline & 2 & K. Lancar & 0 & Rp. 0 & 0 & Rp. 0 \\
\hline & 3 & Diragukan & 0 & Rp. 0 & 0 & Rp. 0 \\
\hline & 4 & Macet & 0 & Rp. 0 & 0 & Rp. 0 \\
\hline & & Jumlah & 85 & Rp. 1.187.160.000 & 124 & Rp. 1.979.892.000 \\
\hline \multirow{5}{*}{$\begin{array}{ll}\text { Bumi } & \text { Kertih } \\
\text { Karanganyar } \\
\text { Desa } \quad \text { Batur } \\
\text { Selatan } & \end{array}$} & 1 & Lancar & 140 & Rp. 272.000 .000 & 110 & Rp. 277.541.000 \\
\hline & 2 & K. Lancar & 48 & Rp. 160.000 .000 & 69 & Rp. 54.271.000 \\
\hline & 3 & Diragukan & 0 & Rp. 0 & 0 & Rp. 0 \\
\hline & 4 & Macet & 10 & Rp. 17.083.000 & 39 & Rp. 63.800 .000 \\
\hline & & Jumlah & 198 & Rp. 449.883.000 & 218 & Rp. 395.612.000 \\
\hline
\end{tabular}

Sumber: Laporan SHU BUMDes Merta Nadi, BUMDes Tri Kerta Praja, BUMDes Amertha Yoni, BUMDes Bumi Kertih Karanganyar (2019 dan 2020).

Berdasarkan tabel perbandingan dari beberapa BUMDes di atas, maka dapat dijelaskan bahwa BUMDes Merta Nadi memiliki jumlah kredit bermasalah pada tahun 2019 berjumlah 
65 orang dengan total nominal sebesar Rp. 281.740 .000 dan pada tahun 2020 jumlah kredit bermasalah pada BUMDes Merta Nadi berjumlah 60 orang dengan total nominal sebesar Rp. 677.250.000. BUMDes Tri Kerta Praja memiliki jumlah kredit bermasalah pada tahun 2019 berjumlah 2 orang dengan total nominal sebesar Rp. 51.000.000 dan pada tahun 2020 jumlah kredit bermasalah pada BUMDes Tri Kerta Praja berjumlah 8 orang dengan total nominal sebesar Rp. 57.833.000. BUMDes Amertha Yoni tahun 2019 dan 2020 tidak mengalami kredit bermasalah. BUMDes Bumi Kertih Karanganyar pada tahun 2019 kredit bermasalah berjumlah 58 orang dengan total nominal sebesar Rp. 177.883 .000 dan pada tahun 2020 jumlah kredit bermasalah sebanyak 108 orang dengan total nominal sebesar Rp. 118.071.000. Berdasarkan tabel 1 dapat disimpulkan bahwa, hal yang membuat peneliti tertarik untuk melakukan penelitian pada BUMDes Merta Nadi adalah jumlah kredit bermasalah, baik jumlah debitur, maupun nominal paling besar, walaupun BUMDes Merta Nadi sudah menerapkan sanksi adat untuk menunjang sanksi administrasi, namun realitanya BUMDes Merta Nadi kredit bermasalahnya paling besar. Fenomena tersebut yang menjadi alasan peneliti tertarik dan termotivasi untuk melakukan penelitian, dimana justru ketatnya sanksi adat yang diberikan dan bersifat komplek pada BUMDes Merta Nadi namun realitanya kredit bermasalah semakin besar baik jumlah debitur maupun nominal.

Perbedaan dan pembaharuan penelitian ini dengan penelitian sebelumnya yang sejenis, yaitu pada penelitian sebelumnya hanya menerapkan sanksi dan prinsip mengkhusus seperti sanksi manusa saksi, dan prinsip pang pade payu sedangkan pada penelitian ini peneliti melakukan penelitian tidak hanya kepada satu sanksi atau satu prinsip, tetapi melalui sanksi adat yang luas/komplek guna mengatasi kredit bermasalah. Penelitian sebelumnya tidak menguraikan secara jelas berapa jumlah total debitur, baik jumlah debitur yang kurang lancar, macet, dan diragukan serta jumlah nominal kredit yang disalurkan dan belum terdapat perbandingan dengan BUMDes-BUMDes lainnya dalam menentukan lokasi penelitian. Penelitian ini menguraikan secara jelas berapa jumlah total debitur, baik jumlah debitur yang lancar, kurang lancar, macet, dan diragukan dalam pembayaran kredit serta membadingkan BUMDes yang dijadikan sebagai lokasi penelitian dan BUMDes-BUMDes lainya.

Berdasarkan uraian diatas, maka dapat ditarik rumusan masalah sebagai berikut: (1) Apa penyebab terjadinya kredit bermasalah pada BUMDes Merta Nadi di Desa Bayung Cerik, (2) Bagaimana strategi dan upaya dalam mengatasi kredit bermasalah pada BUMDes Merta Nadi di Desa Bayung Cerik, (3) Bagaimana efektivitas penerapan sanksi adat dalam mengatasi terjadinya kredit bermasalah pada BUMDes Merta Nadi di Desa Bayung Cerik. Tujuan dari penelitian ini adalah: (1) Untuk mengetahui penyebab terjadinya kredit bermasalah pada BUMDes Merta Nadi di Desa Bayung Cerik, (2) Untuk mengetahui strategi dan upaya dalam mengatasi kredit bermasalah pada BUMDes Merta Nadi di Desa Bayung Cerik. (3) Untuk mengetahui efektivitas penerapan sanksi adat dalam mengatasi terjadinya kredit bermasalah pada BUMDes Merta Nadi di Desa Bayung Cerik.

Provinsi Bali mengenal dua definisi desa, yang pertama menurut batas yang tersirat dan tersurat dalam hukum nasional, dalam konteks ini disebut desa dinas atau desa administratif. Kedua yaitu desa adat atau desa pakraman, mengacu pada masyarakat adat yang terfokus pada ikatan adat dan terkait dengan kehidupan tiga pura besar (kahyangan tiga) (Ernawati, 2019).

Pasal 1 ayat 6 UU No. 6/2014 menyebutkan bahwa Badan Usaha Milik Desa adalah badan usaha yang seluruh atau sebagian modalnya dimiliki oleh desa melalui pernyataan langsung yang bersumber dari kekayaan desa yang dipisahkan untuk mengelola kekayaan, jasa, dan usaha lain untuk kemakmuran masyarakat desa (Sinarwati and Marhaeni, 2019).

Efektivitas adalah suatu ukuran yang menyatakan seberapa jauh target telah tercapai, makin besar persentase target yang dicapai, makin tinggi efektivitasnya (Indrawati, 2017). 
Sistem pengendalian internal menurut Rama dan Jones (dalam Aditya 2017) adalah suatu proses yang dipengaruhi oleh dewan direksi entitas, manajemen dan personel lainnya, yang dirancang untuk memberikan kepastian yang beralasan terkait dengan pencapaian sasaran, yaitu efektivitas dan efisiensi operasi, keandalan laporan dan ketaatan terhadap hukum dan peraturan yang berlaku.

Sihotang (2019) menyatakan bahwa sanksi adat adalah segala bentuk tindakan atau usaha-usaha yang dilakukan untuk mengembalikan ketidakseimbangan termasuk pula ketidakseimbangan yang bersifat magis akibat adanya gangguan yang merupakan pelanggaran adat. Reaksi adat atau sanksi adat di dalam awig-awig dikenal dengan istilah pamidanda. Reaksi atas pelanggaran dalam konsep berpikir hukum adat tidaklah dimaksudkan untuk memberikan derita fisik. Sanksi adat lebih banyak dimaksudkan untuk mengembalikan keseimbangan yang harmonis dan tentram yang diakibatkan oleh adanya pelanggaran adat.

Kredit berasal dari bahasa latin credere yang berarti kepercayaan, oleh karena itu dasar kredit adalah kepercayaan, sehingga apabila seseorang memperoleh kredit berarti mendapat kepercayaan, sedangkan pemberi kredit (kreditur) percaya bahwa penerima kredit (debitur) pada masa yang akan datang sanggup memenuhi segala sesuatu yang telah dijanjikan (Nilawati, 2016).

\section{Metode}

Penelitian ini menggunakan metode penelitian dengan pendekatan kualitatif dan jenis penelitian studi kasus. Lokasi kegiatan dalam penelitian ini, yaitu pada BUMDes Merta Nadi di Desa Bayung Cerik, Kecamatan Kintamani, Kabupaten Bangli. Jenis data dalam penelitian ini adalah data primer dan sekunder, sedangkan sumber data dalam peneliti ini adalah informan penelitian dan instrumen penelitian. Data dikumpulkan dengan cara observasi, wawancara, dan studi dokumentasi. Teknik analisis data pada penelitian ini meliputi pengumpulan data, reduksi data, penyajian data, kesimpulan dan verifikasi. Keabsahan data, sugiyono (2012) mengemukakan teknik pemeriksaan keabsahan data yaitu uji kredibilitas data (validitas internal). Uji kredibilitas data atau kepercayaan terhadap data hasil penelitian kualitatif antara lain dilakukan dengan tringulasi sumber, teknik, dan waktu.

\section{Hasil dan Pembahasan}

\section{Penyebab Terjadinya Kredit Bermasalah pada BUMDes Merta Nadi di Desa Bayung Cerik}

Lembaga keuangan yang ada di desa salah satunya yaitu BUMDes, dalam penyaluran kreditnya BUMDes tentu mengalami permasalahan seperti kredit bermasalah yang disebabkan karena berbagai faktor, salah satu BUMDes yang mengalami permasalahan dalam penyaluran kreditnya yaitu BUMDes Merta Nadi yang berada di Desa Bayung Cerik, Kecamatan Kintamani, Kabupaten Bangli. Penyebab kredit bermasalah pada BUMDes Merta Nadi yaitu karena faktor eksternal, hal ini juga disampaikan oleh ketua BUMDes Merta Nadi pada saat peneliti melakukan wawancara. Berdasarkan pemaparan Ketua BUMDes Merta Nadi yakni Bapak I Wayan Soni pada tanggal 6 Mei 2021 menyatakan bahwa,

"Menurut tyang (saya) faktor-faktor yang menyebabkan kredit bermasalah nike (itu) dari faktor eksternal dik, karena faktor eksternal dari nasabah nike (itu) sangat mempengaruhi penyebab yang menyebabkan kredit masalah punike (itu) dik. Yang pertama dari faktor ekonomi nasabah yang kurang baik mungkin dik, yang kedua masih terdapat masyarakat yang terlambat bayar dengan berbagai alasan (bandel), dan yang terakhir mungkin karena faktor alam atau dari hasil pendapatnya yang tidak kosisten dik, karena dari sektor pertanian seperti jeruk, dari sektor perkebunan 
seperti cabe, tomat dll, dan dari sektor perternakan seperti babi dan sapi nike harganya kadang anjlok kadang bagus dik".

Hal serupa juga disampaikan oleh staf unit usaha simpan pinjam BUMDes Merta Nadi pada saat peneliti melakukan wawancara, dimana berdasarkan hasil wawancara bersama Bapak I Ketut Bayu Suadana selaku staf unit usaha simpan pinjam BUMDes Merta Nadi pada tanggal 6 Mei 2021 menyampaikan bahwa,

"Karena sebagian besar masyarakat di Desa Bayung Cerik yang meminjam memiliki usaha di sektor pertanian, perkebunan, perternakan dan hasil pertanian, perkebunan, perternakan tidak menentu maka hal itu dapat menyebabkan kredit bermasalah dik, dan selain itu kadang ada yang lupa katanya dik, namun ada juga masyarakat yang bandel atau sengaja tidak membayar pinjamannya".

Berdasarkan pernyataan dari ketua BUMDes Merta Nadi dan staf unit usaha simpan pinjam BUMDes Merta Merta Nadi bahwa penyebab terjadinya kredit bermasalah pada BUMDes Merta Nadi yaitu disebabkan oleh faktor eksternal seperti kondisi ekonomi dari debitur BUMDes Merta Nadi yang kurang bagus atau tidak stabil, yang disebabkan oleh hasil dari mata pencaharian debitur BUMDes Merta Nadi, seperti dari sektor pertanian, perkebunan, dan perternakan yang hasilnya tidak menentu terkadang mengalami kenaikan namun juga terkadang mengalami penurunan, selain itu terdapat debitur yang lupa membayar kredit dan ada juga debitur yang memang bandel dalam memayar pinjamannya.

Strategi dan Upaya dalam Mengatasi Kredit Bermasalah pada BUMDes Merta Nadi di Desa Bayung Cerik

BUMDes Merta Nadi dalam pemberian kreditnya tentu memiliki strategi dan upaya dalam mengatasi kredit bermasalah. Strategi dari BUMDes Merta Nadi dalam penyaluran kredit menggunakan prinsip $5 \mathrm{C}$ yaitu Character, Capacity, Capital, Collateral, Conditions, sedangkan upaya yang dilakukan BUMDes Merta Nadi dalam mengatasi kredit bermasalah yaitu memberlakukan/menerapkan sanksi adat dan sanksi administrasi. Pengurus dan pengelola BUMDes Merta Nadi sudah berupaya keras dengan segala strategi untuk mencegah atau mengatasi kredit bermasalah, namun tetap saja terdapat kredit bermasalah, sehingga pengurus dan pengelola BUMDes Merta Nadi harus lebih cepat dan tegas saat bertindak dalam mengatasi kredit bermasalah yang ada.

BUMDes Merta Nadi dalam mengatasi kredit bermasalah, hal yang utama dilakukan yaitu dengan pendekatan secara kekeluargan kepada debitur untuk mendapatkan solusi dalam menyelesaikan kredit bermasalah dan tidak ada pihak yang dirugikan baik itu pihak BUMDes maupun pihak debitur. Tindakan tersebut dilakukan agar tidak menimbulkan masalah baru antara BUMDes dengan debitur. Berdasarkan pemaparan Bapak I Wayan Soni pada tanggal 6 Mei 2021 selaku ketua BUMDes pada saat peneliti melakukan wawancara menyatakan bahwa:

"Strateginya yang kami lakukan hampir sama dengan lembaga keuangan lainnya seperti prinsip 5C tersebut yaitu kami dari pihak BUMDes melihat kepribadian atau karakternya, melihat kemampuan nasabah dalam melunasi pinjaman, melihat kondisi aset dan kekayaan dari nasabah, melihat jaminannya, melihat kondisi dari luar juga misalnya apakah nasabah diluar juga melakukan pinjaman, melihat usia jaminan dan kondisi lainnya juga. Sedangkan upaya yang dilaukan oleh pihak BUMDes mungkin cukup berbeda dengan lembaga keuangan lainnya karena kami 
dari pihak BUMDes menerapkan sanksi adat guna menunjang strategi dalam penyaluran kredit dan snaksi administrasi sesuai dengan AD/ART desa, dimana seperti yang kita ketahui di Bali niki (ini) adatnya sangat kuat dan kental".

Pernyataan ketua BUMDes juga dikudung oleh hasil wawancara peneliti dengan Bapak I Ketut Bayu Suadana selaku staf unit usaha simpan pinjam BUMDes Merta Nadi pada tanggal 6 Mei 2021 yang menyampaikan bahwa,

"Strategi yang dilakukan oleh pihak BUMDes biasanya menerapkan prinsip $5 \mathrm{C}$, yaitu melihat kepribadian atau karakter dari nasabah, melihat kemampuan nasabah dalam melunasi pinjaman, melihat kondisi aset dan kekayaan nasabah, jaminan, kondisi dari luar misalnya minimal peminjaman, melihat usia jaminan dan kondisi lainnya. Untuk menunjang strategi tersebut pihak BUMDes melakukan upaya yaitu dengan menerapan sanksi adat guna menunjang strategi pemberian kredit dan menunjang sanksi administrasi sesuai dengan AD/ART”.

Berdasarkan pernyataan yang disampaikan dari ketua BUMDes Merta Nadi dan staf unit usaha simpan pinjam BUMDes Merta Merta Nadi bahwa strategi dan upaya yang dilakukan oleh pihak BUMDes Merta Nadi dalam mengatasi kredit bermasalah yaitu dengan strategi pemberian kredit berdasarkan prinsip 5C, diantaranya: (1) Character seperti melihat kepribadian atau karakter dari debitur agar pada saat diberikan kredit benar-benar dapat dipercaya, hal ini tercermin dari latar belakang si debitur baik dari pekerjaan maupun yang bersifat pribadi seperti: gaya hidup, keadaan keluarga dan sebagainya. (2) Capacity seperti melihat kemampuan debitur dalam melunasi pinjaman, agar BUMDes Merta Merta Nadi yakin bahwa usaha yang akan dibiayai dengan kredit tersebut dikelola oleh orang-orang yang tepat/benar. (3) Capital seperti melihat kondisi modal debitur, semakin banyak modal yang ditanamkan, debitur akan dipandang semakin serius dalam menjalankan usahanya. (4) Collateral seperti melihat jaminan yang dimiliki oleh debitur baik yang bersifat fisik maupun non fisik. Jaminan hendaknya melebihi jumlah kredit yang diberikan untuk berjaga-jaga seandainya debitur tidak dapat mengembalikan pinjamannya. (5) Conditions seperti melihat usia minimal peminjam, jumlah pinjaman, atau kondisi lainnnya yang telah ditetapkan oleh BUMDes Merta Nadi kepada debitur.

Upaya yang dilakukan BUMDes Merta Nadi berdasarkan pernyataan yang disampaikan dari ketua BUMDes Merta Nadi dan staf unit usaha simpan pinjam BUMDes Merta Merta Nadi bahwa pihak BUMDes melakukan upaya yakni dengan menerapan sanksi adat seperti debitur yang mempunyai kredit namun tidak memiliki inisiatif membayar kreditnya dan tidak bisa diselesaikan dengan cara pendekatan kekeluargaan dan atau dengan prosedur penagihan yang telah ditetapkan oleh BUMDes Merta Nadi antara lain: (1) Dilakukan penagihan oleh bagian penagihan dan Ketua BUMDes, (2) Pemberian Surat Peringatan (SP) 1-3, (3) Melaporkan masyarakat yang bersangkutan kepada Bendesa adat/Kelian adat, (4) Dilakukan pendekatan secara ke keluargaan oleh Bendesa adat/Kelian adat dan dicari pemecahan masalah sesuai permasalahan yang dialami oleh masyarakat, (5) Jika masyarakat yang bersangkutan tetap tidak mau membayar, maka akan dilaporkan ke Perbekel dan akan dikenakan sanksi administrasi dan sanksi adat tersebut.

Mekanisme penerapan sanksi adat terhadap debitur, yaitu debitur tidak akan mendapatkan pelayanan dari sulinggih/pemangku, bendesa, kelian dinas, kelian adat, serta kelian banjar dalam upacara tiga bulanan, mecaru, mepejati, pernikahan, piodalan, mesangih dan upacara/upakara adat lainnya, karena dalam uparaca/upakara tersebut harus terdapat pemangku yang memimpin upacara/upakara dan di saksikan oleh bendesa dan kelian-kelian desa tersebut. Sanksi adat merupakan upaya yang dilakukan oleh pihak BUMDes guna 
menunjang strategi pemberian kredit dan menunjang sanksi administrasi sesuai dengan AD/ART desa, serta karena melihat kuat dan kentalnya pengaruh adat di Bali. Sanksi adat dapat dicabut sampai debitur tersebut melunasi tunggakannya.

\section{Efektivitas Penerapan Sanksi Adat dalam Mengatasi Terjadinya Kredit Bermasalah pada BUMDes Merta Nadi di Desa Bayung Cerik}

Desa Bayung Cerik mendirikan BUMDes bersama-sama antara desa dinas dengan desa adat karena kuatnya pengaruh adat serta sinergi antara desa dinas dengan desa adat. BUMDes tersebut diharapkan mampu meningkatkan pendapatan asli desa dalam rangka meningkatkan kemampuan pemerintahan desa, mengembangkan potensi perekonomian desa, meningkatkan perekonomian masyarakat desa, dan juga mampu menciptakan lapangan pekerjaan bagi masyarakat Desa Bayung Cerik. BUMDes Merta Nadi memberlakukan atau menerapkan dua sanksi untuk menjaga keberlansungan perkembangan dan kemajuannya dalam pemberian kredit yaitu dengan memberlakukan atau menerapkan sanski adat dan sanksi administrasi untuk mengatasi kredit bermasalah.

Berdasarkan hasil wawancara peneliti dengan Bapak I Wayan Kumpul selaku Perbekel Desa Bayung Cerik pada tanggal 6 Mei 2021 menyatakan bahwa,

"Karena sesuai dengan hasil musyawarah bersama tokoh-tokoh masyarakat seperti pemangku, bendesa, kelian adat banjar, BPD, LPM yang mewakili dari pada masyarakat bahwa desa dinas selalu bersinergi dengan desa adat karena kuatnya pengaruh adat di Bali, maka dari itu sanksi adat diberlakukan di BUMDes Merta Nadi”.

Mengingat pentingnya pelayanan adat dari pemangku/sulinggih, bendesa, kelian adat, dan tokoh-tokoh masyarakat lainnya dalam setiap upacara/upakara yadnya baik itu upacara tiga bulanan, mesangih, pawiwahan, mecaru, mepejati, dan upacara/upakara lainnya. Melihat hal tersebut maka sanksi adat sangat diperlukan dalam mengatasi kredit bermasalah di BUMDes Merta Nadi. Berdasarkan pemaparan Bapak I Wayan Soni selaku ketua BUMDes Merta Nadi pada tanggal 6 Mei 2021 menyatakan bahwa,

"Penerapan sanksi adat biasanya tidak mendapatkan pelayanan dari sulinggih atau pemangku, bendesa, kelian adat banjar dan tokoh-tokoh desa bagi nasabah yang memiliki kredit bermasalah yang tidak bisa diselesaikan secara kekeluargaan. Karena seperti yang kita tahu bahwa di Bali adatnya sangat kuat, maka dari itu sanksi adat diterapkan. Sanksi adat dan sanksi administrasi dapat di cabut apabila tunggakan tersebut dilunasi dik".

Sanksi adat merupakan sanksi yang diberikan kepada debitur BUMDes Merta Nadi apabila debitur masih memiliki tunggakan dalam hal pembayaran dan tidak bisa ditagih atau diselesaikan dengan cara kekeluargaan dan atau dengan prosedur penagihan yang telah ditetapkan oleh BUMDes Merta Nadi, antara lain: (1) Dilakukan penagihan oleh bagian penagihan dan Ketua BUMDes, (2) Pemberian Surat Peringatan (SP) 1-3, (3) Melaporkan masyarakat yang bersangkutan kepada Bendesa adat/Kelian adat, (4) Dilakukan pendekatan secara ke keluargaan oleh Bendesa adat/Kelian adat dan dicari pemecahan masalah sesuai permasalahan yang dialami oleh masyarakat, (5) Jika masyarakat yang bersangkutan tetap tidak mau membayar, maka akan dilaporkan ke Perbekel dan akan dikenakan sanksi administrasi dan sanksi adat tersebut. 
Sanksi adat akan diterakan jika hal-hal diatas belum bisa membuat debitur mau dan mempunyai itikad untuk membayar tunggakannya, maka debitur tersebut akan dikenakan sanksi adat yaitu tidak diberikan pelayanan adat dari pemangku/sulinggih, bendesa, kelian adat, dan tokoh-tokoh masyarakat lainnya dalam setiap upacara/upakara yadnya baik itu upacara tiga bulanan, mesangih, pawiwahan, mecaru, mepejati, dan upacara/upakara lainnya samapai tunggakan tersebut dilunasi. Pemberlakukan sanksi adat yang diterapkan pada BUMDes Merta Nadi di Desa Bayung Cerik, Kecamatan Kintamani, Kabupaten Bangli sudah berjalan cukup efektif, karena sanksi adat ini dapat mengatasi kredit bermasalah pada BUMDes Merta Nadi dan sejauh ini belum ada debitur yang sampai dikenakan sanksi adat. Berdasarkan hasil wawancara yang dilakukan peneliti kepada informan dinyatakan bahwa sanksi adat cukup efektif dalam mengatasi kredit bermasalah pada BUMDes Merta Nadi, walaupun masih terdapat debitur yang kurang lancar dalam pembayarannya. Berdasarkan pemaparan Bapak I Wayan Kumpul selaku Perbekel Desa Bayung Cerik pada tanggal 5 Mei 2021 menyatakan bahwa,
"Secara pribadi menurut bapak cukup efektif dik, karena sampai saat ini belum ada masyarakat yang sampai diberikan atau dikenakan sanksi adat tersebut, namun jika dilihat dari nasabah, memang masih ada yang kurang lancar untuk membayar pinjamannya, itu mungkin karena hasil pendapatannya tidak lancar, karena pertanian seperti jeruk, perkebunan seperti cabe, dan peternakan seperti babi harganya kadang anjlok dan kurang bagus, mungkin itu yang menyebabkan masih ada nasabah yang kurang lancar dalam membayar pinjamannya dik. Yen (kalau) kasarne (kasarnya) sanksi adat niki (ini) ngae (membuat) msayarakat lek (malu) pasti yen (kalau) sampai dikenakan sanksi adat niki (ini). Selama ini masyarakat ngelah (mempunyai) rasa kesadaran ye (dia) nyak (mau) mayah (bayar) kredit, karna (karena) takut ajak (dan) lek (malu) yen (kalau) sampai kene (dikenakan) sanksi adat nike (ini) apalagi sampai sing (tidak) dilayani di adat, maka ulian (dari) to (itu) masyarakat berusaha apang (biar) ngidang (bisa) mayah (bayar) apang (biar) sing (tidak) sampai kene (kena) sanksi adat, walaupun keweh (susah) tetapi tetep nyak (mau) meuleh-ulehan (berusaha) pang (biar) ngidaang (bisa) mayah (bayar)".

Sanksi adat juga bisa diterima oleh masyarakat selaku debitur pada BUMDes Merta Nadi sehingga penerapan sanksi adat dapat dijalankan dengan baik sampai saat ini. Berdasarkan pemaparan Bapak I Nyoman Wertayasa selaku debitur BUMDes Merta Nadi pada tanggal 7 Mei 2021 yang menyampaikan bahwa,

"Nggih (iya) tyang (saya) setuju, karena sanksi tersebut dapat mencegah dan mengurangi nasabah untuk tidak bandel (nakal) utawi (atau) ten (tidak) mayah (bayar) kredit dik".

Sanksi adat juga tidak memberatkan masyarakat selaku debitur pada BUMDes Merta Nadi sehingga penerapan sanksi adat dapat dijalankan dengan baik sampai saat ini, hal ini juga disampaikan debitur BUMDes Merta Nadi pada saat peneliti melakukan wawancara bersama debitur selaku informan. Berdasarkan pemaparan Bapak I Wayan Subadra selaku debitur BUMDes Merta Nadi pada tanggal 7 Mei 2021 yang menyampaikan bahwa,

"Kalau menurut tyang (saya) sendiri tidak memberatkan sama sekali, dan justru sangat bagus di terapkan karena bisa menekan nasabah pang (biar) ten (tidak) bandel (nakal) dalam melunasi kreditnya". 
Berdasarkan pernyataan yang disampaikan oleh Perbekel Desa Bayung Cerik dan Ketua BUMDes Merta Nadi bahwa penerapan sanksi adat pada BUMDes Merta Nadi terbilang cukup efektif karena dari awal pendirian BUMDes sampai saat ini belum ada debitur yang sampai dikenakan sanksi adat tersebut, namun jika dilihat dari debitur, memang masih ada yang kurang lancar dalam membayar pinjamannya, mungkin hal tersebut terjadi karena hasil pendapatannya yang tidak lancar, karena pertanian, perkebunan, dan peternakan dari usaha debitur harganya kadang anjlok dan kurang bagus, hal itulah yang menyebabkan masih ada debitur yang kurang lancar dalam membayar pinjamannya. Penerapan sanksi adat tersebut dapat menumbuhkan rasa malu debitur dan kesadaran untuk melunasi tunggakannya, serta berusaha untuk membayar tunggakannya walaupun usaha atau penghasilannya kadang kurang bagus. Indikator yang menyatakan penerapan sanksi adat di katakan cukup efektif karena dilihat dari jumlah nominal kredit macet di tahun 2019 sebesar Rp. 11.380 .000 dan di tahun 2020 sebesar Rp. 5.200.000, dilihat dari tahun 2019 ke tahun 2020 kredit macet mengalami penurunan sebesar Rp. 6.180.000. Indikator lain yang menyatakan penerapan sanksi adat dikatakan cukup efektif karena dilihat dari peningkatan kredit lancar dengan jumlah debitur ditahun 2019 sebanyak 115 dan tahun 2020 sebanyak 121, dilihat dari tahun 2019 ke tahun 2020 kredit lancar mengalami peningkatan sebanyak 6, sedangkan jumlah nominal ditahun 2019 sebesar Rp. 1.245.265.000 dan ditahun 2020 sebesar Rp. 1.429.650.000, untuk jumlah nominal ditahun 2019 dan ditahun 2020 juga mengalami peningkatan sebesar Rp. 184.385.000.

\section{Simpulan dan Saran}

Dari penelitian yang telah dilakukan, dapat ditarik kesimpulan mengenai analisis efektivitas sistem pengendalian internal melalui sanksi adat dalam upaya mengatasi kredit bermasalah pada BUMDes Merta Nadi di Desa Bayung Cerik adalah 1) Penyebab terjadinya kredit bermasalah pada BUMDes Merta Nadi yaitu disebabkan oleh faktor eksternal seperti kondisi ekonomi dari debitur BUMDes Merta Nadi yang kurang bagus atau tidak stabil, yang disebabkan oleh hasil dari mata pencaharian debitur BUMDes Merta Nadi, seperti dari sektor pertanian, perkebunan, dan perternakan yang hasilnya tidak menentu terkadang mengalami kenaikan namun juga terkadang mengalami penurunan, selain itu terdapat debitur yang lupa membayar kredit dan ada juga debitur yang memang bandel dalam memayar pinjamannya., 2) Strategi dan upaya yang dilakukan oleh pihak BUMDes Merta Nadi dalam mengatasi kredit bermasalah yaitu dengan strategi pemberian kredit berdasarkan prinsip 5C, diantaranya: (1) Character seperti melihat kepribadian atau karakter dari debitur, (2) Capacity seperti melihat kemampuan debitur, (3) Capital seperti melihat kondisi modal debitur, (4) Collateral seperti melihat jaminan yang dimiliki oleh debitur, (5) Conditions seperti melihat usia minimal peminjam. Upaya yang dilakukan BUMDes Merta Nadi yakni dengan menerapan sanksi adat seperti debitur yang mempunyai kredit namun tidak memiliki inisiatif membayar kreditnya dan tidak bisa diselesaikan dengan cara pendekatan kekeluargaan dan atau dengan prosedur penagihan yang telah ditetapkan oleh BUMDes Merta Nadi, 3) Penerapan sanksi adat pada BUMDes Merta Nadi terbilang cukup efektif, karena dari awal berdiri debitur BUMDes Merta Nadi tidak ada yang sampai dikenakan sanksi adat tersebut. Penerapan sanksi adat juga berimplikasi baik karena dapat menumbuhkan rasa malu debitur, sadar, dan berusaha dalam membayar kredit agar tidak sampai dikenakan sanksi adat maupun sanksi administrasi. Penerapan sanksi adat pada BUMDes Merta Nadi terbilang cukup efektif, karena dari awal berdiri debitur BUMDes Merta Nadi tidak ada yang sampai dikenakan sanksi adat tersebut. Penerapan sanksi adat juga berimplikasi baik karena dapat menumbuhkan rasa malu debitur, sadar, dan berusaha dalam membayar kredit agar tidak sampai dikenakan sanksi adat maupun sanksi administrasi. Indikator yang menyatakan 
penerapan sanksi adat di katakan cukup efektif karena dilihat dari jumlah nominal kredit macet di tahun 2019 sebesar Rp. 11.380 .000 dan di tahun 2020 sebesar Rp. 5.200.000, dilihat dari tahun 2019 ke tahun 2020 kredit macet mengalami penurunan sebesar Rp. 6.180.000. Indikator lain yang menyatakan penerapan sanksi adat dikatakan cukup efektif karena dilihat dari peningkatan kredit lancar dengan jumlah debitur ditahun 2019 sebanyak 115 dan tahun 2020 sebanyak 121, dilihat dari tahun 2019 ke tahun 2020 kredit lancar mengalami peningkatan sebanyak 6, sedangkan jumlah nominal ditahun 2019 sebesar Rp. 1.245.265.000 dan ditahun 2020 sebesar Rp. 1.429.650.000, untuk jumlah nominal ditahun 2019 dan ditahun 2020 juga mengalami peningkatan sebesar Rp. 184.385.000.

Berdasarkan simpulan diatas, ada beberapa saran yang dapat diberikan dalam penelitian ini yaitu 1) Bagi BUMDes Merta Nadi Desa Bayung Cerik, Kecamatan Kintamani, Kabupaten Bangli, dalam mengatasi kredit bermasalah pihak BUMDes diharapkan bisa lebih meningkatkan sistem pengendalian internalnya sehingga mampu menerapkan strategi dan upaya dengan lebih baik serta pihak BUMDes diharapkan bisa lebih tegas agar kredit bermasalah dapat diatasi dengan lebih baik tanpa merugikan berbagai pihak, 2) Bagi masyarakat desa di Desa Bayung Cerik, Kecamatan Kintamani, Kabupaten Bangli, agar tetap mengingat kewajibannya untuk membayar kredit tepat waktu, pada BUMDes dan lembaga keuangan lainnya dan terus ikut berpartisipasi dalam mengembangkan BUMDes agar nantinya BUMDes dan Desa Bayung Cerik dapat menjadi lebih maju dan sejahtera lagi perekonomiannya.

\section{Daftar Pustaka}

Aditya, I Ketut, Kuntara Wijaya, Made Aristia Prayudi, and Gede Adi Yuniarta. 2017. "Analisis Sistem Pengendalian Internal Atas Retribusi Parkir Dalam Meminimalkan Tindakan Pungutan Liar." E-journal Akuntansi, Universitas Pendidikan Ganesha Singaraja 1: 10.

Indrawati, Komang Ayu Pradnya, Dkk. 2017. "Efektivitas Iklan Melalui Media Sosial Facebook Dan Instagram Sebagai Salah Satu Strategi Pemasaran Di Krisna Oleh-Oleh Khas Bali." Analisis Pariwisata 17(2): 78-83.

Nilawati, Ni Komang. 2016. "Sistem Pengendalian Intern Pemberian Kredit Pada Badan Usaha Milik Desa (BUMDes) Desa Pengastulan, Kecamatan Seririt, Kabupaten Buleleng." Jurnal Program Studi Pendidikan Ekonomi (JPPE) 7(2).

Sihotang, E. 2019. "Sanksi Adat Dan Pidana Yang Berbarengan Dalam Tindak Pidana Pencabulan Anak Kaitannya Dengan Asas Nebis In Idem (Studi Di Desa Adat Tanglad, Kecamatan Nusa Penida, Kabupaten Klungkung).” Mimbar Keadilan 12(2): 211.

Sinarwati, Ni Kadek, and AAIN Marhaeni. 2019. "Peran Usaha Sendiri Desa Terhadap Pembangunan Pedesaan." 18. 